\title{
Questions and answers
}

\section{Preguntas y respuestas}

\author{
Fernando Raffán-Sanabria a,b,c (iD \\ ${ }^{a}$ Intensive care anesthetist, Hospital Universitario Fundación Santa Fe de Bogotá. Bogotá, Colombia \\ ${ }^{\mathrm{b}}$ Faculty, Universidad El Bosque. Bogotá, Colombia \\ ' Faculty, Universidad de los Andes. Bogotá, Colombia \\ Correspondence: Sociedad Colombiana de Anestesiología y Reanimación (S.C.A.R.E.). Carrera 15A \# 120-74. Bogotá, Colombia. \\ E-mail: raffanmago@gmail.com
}

How to cite this article

Raffán-Sanabria F. Questions and answers. Colombian Journal of Anesthesiology. 2020;48(4):e938.

1. In 2019, the Pan-American Federation of Medical Schools (Fepafem, in Spanish), signed a declaration stating that education institutions must promote dynamic, top-quality, competencybased training processes. The name of that declaration is(1):
a. Cartagena.
b. Lima.
c. Buenos Aires.
d. Montreal.

2. The so-called anesthesia awareness (AA) is a complication associated with different postoperative manifestations including sleep disorders, depressive episodes and fear of hospital settings. Which of the following statements regarding AA is false?(2)

a. Incidence varies significantly between 1:600 and 1:17,000 patients.

b. It may give rise to states of post-traumatic stress.

c. The use of BIS to monitor the depth of anesthesia reduces the incidence of AA by $95 \%$.

d. Auditory evoked potentials have been used to determine the level of patient unconsciousness.

3. Targeted temperature management is a neuroprotective strategy used in the management of patients in cardiorespiratory arrest. The current recommendation is to maintain body temperature between(3):
a. 32.5 and $34^{\circ} \mathrm{C}$.
b. 32 and $36^{\circ} \mathrm{C}$.
c. 33 and $35^{\circ} \mathrm{C}$.
d. 34 and $36^{\circ} \mathrm{C}$.

4. In their meta-analysis, "Mortality in patients with civilian trauma and massive transfusion treated with a high plasma-to-red blood cells ratio vs. a low ratio" ("Mortalidad en pacientes con trauma civil y transfusión masiva tratados con una relación alta de plasma: glóbulos rojos versus una relación baja"), Oliveros Rodríguez et al. found that (4):

a. The use of a high FFP:RBC ratio in patients with civilian trauma and massive transfusion has a protective effect on early and late mortality as shown in observational studies (OS) but not so in clinical trials (CT).

b. The use of a high FFP:RBC ratio in patients with civilian trauma and massive transfusion does not have a protective effect on early mortality, but it does on late mortality, as shown in both OS as well as CTs.

c. The use of a high FFP:RBC ratio in patients with civilian trauma and massive transfusion does not have a protective effect on early or late mortality as shown in OS and CTs.

d. The use of a high FFP:RBC ratio in patients with civilian trauma and massive transfusion has a protective effect on early and late mortality as shown both in OS as well as in CTs.

5. Which of the following airborne viral species is generally the most lethal?(5)
a. $\mathrm{H}_{1} \mathrm{~N} 1$.
b. SARS-CoV.
c. MERS-CoV.
d. SARS-CoV-2. 
6. The term technical skills refers to performance of actions from the point of view of medical knowledge as well as from a technical perspective. They are based on body and mind control and are divided into open and closed. Which of the following technical skills is considered open?(6)
a. Orotracheal intubation.
b. Vascular catheterization.
c. Regional anesthesia.
d. Difficult airway management.

7. Which of the following biomarkers is not recognized as a useful prognostic factor in patients with head injury?(7)
a. S-10ob protein.
b. Ubiquitin C-terminal hidrolase-L1.
c. Glial fibrillary acid protein.
d. Brain natriuretic peptide.

8. Classic mitotic dystrophy is a multisystem disorder resulting from RNA toxicity and is one of the most common muscle dystrophies in adults. Which is the most frequently observed electrocardiographic abnormality in these patients?(8)
a. First-degree AV block.
b. Second-degree Mobitz type I AV block.
c. Second-degree Mobitz type II AV block.
d. Third-degree AV block.

9. Erector spinae plane (ESP) block is a safe interfascial block. Regarding this block, which of the following statements is true?(9)
a. This block provides only somatic analgesia.
b. Only provides visceral analgesia.

c. May be an effective approach for intra-and postoperative analgesia in high risk patients taken to laparoscopic liver resection.

d. It is contraindicated in patients with cardioverter-defibrillator.

10. Bupivacaine-induced myotoxicity is, fortunately, a rare complication. However, studies have described it both in human as well as in experimental animal cells. Disease severity risk factors include prior mitochondrial metabolism anomalies with compromised energy production, for example, in patients with $\underline{(10)}$ :
a. Chronic hipoxemia.
b. Diabetes mellitus type 2 .
c. Statin treatment.
d. All of the above.

\section{REFERENCES}

1. Kealey A. Competency-based medical education: don 't wait for change, lead it! Colombian Journal of Anesthesiology. 2020;48:107-10. DOI: https://doi.org/10.1097/ C]9.0000000000000170

2. Oliveros H, Ríos F, Botero-Rosas DA, Quiroga SC, Cifuentes FC, Rodríguez GA, Morales MP. Variability of anesthetic depth in total intravenous anesthesia vs. balanced anesthesia using entropy indices: a randomized, crossover, controlled clinical trial. Colombian Journal of Anesthesiology. 2020;48:111-7. DOI: https:// doi.org/10.1097/C]9.0000000000000163

3. Villa-Velásquez JC, Hoyos-Vanegas NA, Cómez-Echeverry JC, Payares-Benítez A, Casas-Arroyave FD. Cardiac arrest in adult intensive care units in the Medellin metropolitan area, Colombia: observational study. Colombian Journal of Anesthesiology. 2020;48:118-25. DOI: https://doi.org/10.1097/ C]9.0000000000000156

4. Oliveros Rodríguez H, Ríos F, Rubio C, Arsanios DM, Herazo AF, Beltrán LM, García P, Cifuentes A, Muñoz ], Polanía ]. Mortality in civilian trauma patients and massive blood transfusion treated with high vs low plasma: red blood cell ratio. Systematic review and meta-analysis. Colombian Journal of Anesthesiology.
2020;48:126-37. DOI: https://doi.org/10.1097/ C]9.0000000000000161

5. Calabrese G. Update on biological risk for anesthetists taking care of patients affected by SARS$\mathrm{CoV} 2$, COVID19. Colombian Journal of Anesthesiology. 2020;48:138-144. DOI: https://doi. org/10.1097/C]9.0000000000000173

6. Jaramillo-Rincón SX, Durante E, Ladenheim R, Díaz-Cortés JC. Anesthesia assessment in the era of competences: state of the art. Colombian Journal of Anesthesiology. 2020;48:145-54. DOI: https://doi.org/10.1097/ C]9.0000000000000158

7. Mendoza DA, López KD, Echeverri RA, Pastor L, Rueda S, Fernández LL, Mantilla DS, Díaz MF, Ramírez MC, Barragán DC, Rubiano AM. Utility of biomarkers in traumatic brain injury: a narrative review. Colombian Journal of Anesthesiology. 2020;48:155-61. DOI: https:// doi.org/10.1097/Cl9.0000000000000165

8. Khanna S, Bustamante S. Cardiac conduction defects and complete heart block in myotonic dystrophy. Colombian Journal of Anesthesiology. 2020;48:162-3. DOI: https://doi. org/10.1097/C]9.0000000000000155

9. Piangatelli C, Dalla Bona E, Tavoletti D, Rosanò $\mathrm{E}$, Mocchegiani F, Vivarelli M, Cerutti $\mathrm{E}$. Continuous erector spinae plane block for pain management in laparoscopic liver resection: case report. Colombian Journal of Anesthesiology. 2020;48:164-8. DOI: https://doi. org/10.1097/C]9.0000000000000167

10. Dorado-Velasco FC, Loaiza-Ruiz DM, Llinás-Hernández PJ, Huependo CAH. Miotoxicidad inducida por bupivacaína durante un bloqueo continuo del nervio femoral: reporte de caso. Case-control study. Colombian Journal of Anesthesiology. 2020;48:169-73. DOI: https://doi.org/10.1097/ C]9.0000000000000104

\section{RESPUESTAS}

1.a.

2. c.

3. b.

4. a.

5. c.

6. d.

7.d.

8. a.

9. $c$.

10. d. 